\title{
Resistance of Landscape-Suitable Elms to Japanese Beetle, Gall Aphids, and Leaf Miners, with Notes on Life History of Orchestes alni and Agromyza aristata in Kentucky
}

\author{
Jennie M. Condra, Cristina M. Brady, and Daniel A. Potter
}

\begin{abstract}
Twenty genotypes of landscape-suitable Dutch elm disease-resistant elms (Ulmus spp.) were evaluated in a replicated field study for resistance to multiple insect pests in Lexington, Kentucky, U.S. The European elm flea weevil (EEFW), Orchestes alni, a recently-introduced pest that disfigures elms by leaf-mining and adult feeding, was found as a new state record so its feeding preferences and life history were monitored. U. parvifolia and U. propinqua, originally from Japan, were relatively resistant to Japanese beetles, and $U$. americana was generally less susceptible than most hybrids. Agromyza aristata, a serpentine leaf-mining fly, favored American elms, whereas Kaliofenusa ulmi a blotch-mining sawfly, and aphid (Tetraneura nigriabdominalis) pouch galls were uncommon on American and Asian elms but abundant on certain hybrids. EEFW infested all elms but at highest densities, (>20 mines per $30 \mathrm{~cm}$ shoot and $>85$ adult feeding holes per leaf), on certain hybrids. American elms, especially 'Jefferson', were somewhat less susceptible. EEFW laid eggs in expanding leaves; mines were initiated in late April and completed by mid- to late- May. Newly-emerged adults extensively damaged leaves in late May and June but nearly disappeared from tree canopies by mid-July. Implications for re-introduction of elms into urban landscapes are discussed.

Key Words. Agromyza aristata; Dutch Elm Disease; Integrated Pest Management; Kalifenusa ulni; National Elm Trial; Orchestes alni; Tetraneura nigriabdominalis; Ulmus spp.
\end{abstract}

Elms (Ulmus spp.), particularly the stately American elm (Ulmus americana), were once the dominant street and shade trees in cities and towns throughout North America (Hubbes 1999). Dutch elm disease (DED), which had already devastated elms in Europe, was first discovered in the United States in 1930 and quickly spread throughout eastern North America from several infection centers (Stipes and Campana 1981; Hubbes 1999). DED is caused by the wilt fungus Ophiostoma ulmi and is vectored by two species of elm bark beetles (Scolytidae). By 1977, pandemics of DED had killed approximately $56 \%$ of the original elm population in the eastern United States, roughly 43 million trees, causing great economic and aesthetic loss (Hubbes 1999; Merkle et al. 2007).

Selection and breeding efforts to develop hardy DED-resistant American and hybrid elms have been underway for more than 70 years (Smalley and Guries 1993; Merkle et al. 2007). Although straight selection by inoculation screening has resulted in several DED-resistant pure American elm cultivars that were released to nurseries (Merkle et al. 2007), all North American elm species are susceptible (Hubbes 1999). Thus, the main sources for DED resistance genes are Asian elm species; e.g., U. parvifolia, $U$. pumila, $U$. propinqua, U. japonica, U. wilsoniana, and others (Smalley and Guries 1993; Hubbes 1999). DED fungus likely originated in the Himalayas (Brasier and Mehrotra 1995); thus, Asian elms may have had longer evolutionary time to develop resistance. A number of DED-resistant hybrid elms have been developed from genetic combinations of Asian and, to lesser extent, European gene pools (Smalley and Guries 1993). Their growth habit, leaf size, and hardiness vary across different regions, however, so does their resistance to pests other than Dutch elm disease (Smalley and Guries 1993; Miller 2000; Bosu et al. 2007).

Increasing pressure on shade trees from exotic pests such as emerald ash borer (Agrilus planipennis), Asian longhorned beetle (Anoplophora glabripennis), hemlock woolly adelgid (Adelges tsugae), and the sudden oak death/decline fungus (Phytopthora ramorum), as well as native pests such as bacterial leaf scorch (Xylella fastidiosa) underscores the importance of diversifying urban forests (Raupp et al. 2006). There is renewed interest in returning DED-resistant American and hybrid elms to streets and landscapes. To reduce the need for pesticide usage, however, trees ideally should also be resistant to other pest species.

The National Elm Trial is a cooperative effort to evaluate DED-resistant, commercially available American and hybrid elms for horticultural characteristics and suitability for use across a range of environmental conditions in the United States (Jacobi et al. 2009). Large, replicated field trials were planted in 15 states, including Kentucky, providing the opportunity for evaluating elms of differing parentage for susceptibility to multiple insect pests. The authors report here on the relative resistance of 20 species and cultivars of DEDresistant, landscape-suitable elms to three species of leaf miners, pouch gall aphids, and Japanese beetles (Popillia japonica).

One of the leaf miners found at the current study site was the European elm flea weevil (EEFW), Orchestes alni (Figure 1; Figure 2), an invasive pest first reported in the United States 
in 2003. Prior to 2007, EEFW had been documented only in the Illinois and Wisconsin states (Anderson et al. 2007). Another leafminer, Agromyza aristata, was also abundant. As there is little published information on the biology of either species, their seasonal life histories in Kentucky are also reported here.

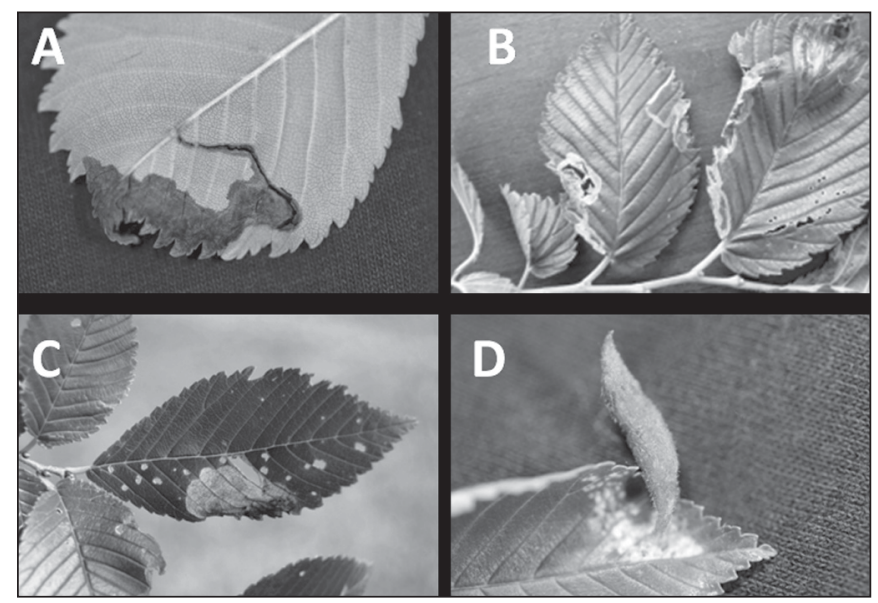

Figure 1. Leaf mines and aphid pouch galls evaluated on trees in the National Elm Trial site in Lexington, Kentucky: (a) serpentineblotch mine of Orchestes alni; (b) serpentine mine of Agromyza aristata, (c) Blotch mine of Kaliofenusa ulmi, (d) gall induced by Tetraneura nigriabdominalis.

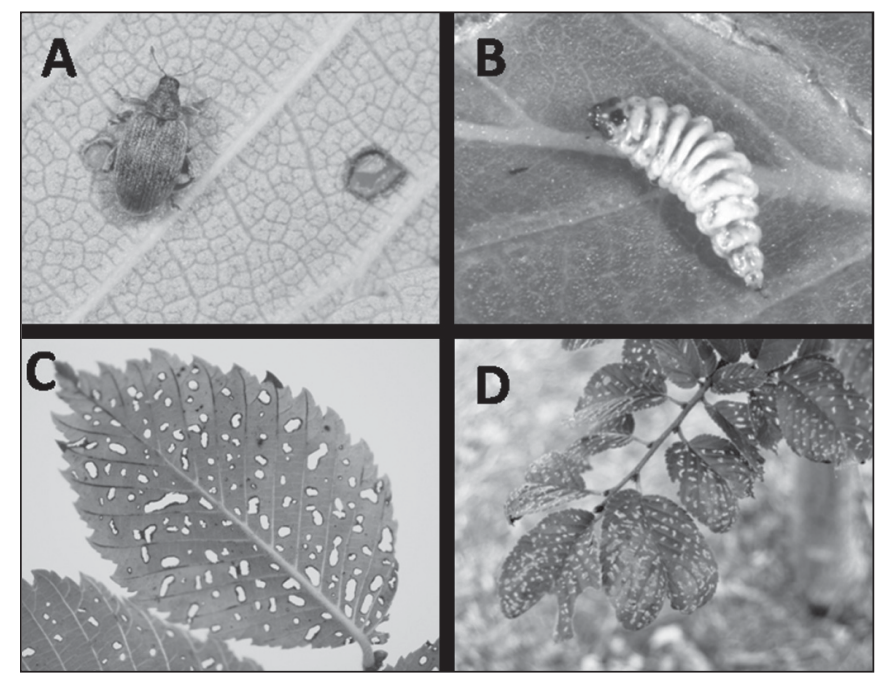

Figure 2. Life stages and symptoms of European elm flea weevil, Orchestes alni: (a) adult weevil, (b) larva removed from mine, (c, d) adult feeding injury. A typical mine is shown in Figure 1.

\section{METHODS AND MATERIALS}

The main study site was an open, grassy area on Maury silt loam soil on the University of Kentucky campus in Lexington, Kentucky, adjacent to the Arboretum and State Botanical Garden of Kentucky (N38 $1^{\prime}$; W84 $30^{\circ}$; elevation 302 m). Five replicates of 20 elm cultivars, including North American, Asian, and European species and hybrids (Table 1), were planted in a randomized complete block in rows spaced $7.6 \mathrm{~m}$ apart, with $7.6 \mathrm{~m}$ between trees within rows and
$50 \mathrm{~m}$ between replicates. Seventeen cultivars were planted in spring 2005; three others were planted in randomized spaces left in each block in spring 2006 or 2007 . The trees were obtained from nurseries as bare-root transplants and ranged from 1.5-2.4 m height at time of planting. They were staked, watered as needed, and mulched over grass that had been killed with glyphosate herbicide.

Many of the cultivars have dissimilar leaf size, so 20 fully expanded leaves were collected from each tree in early June 2009 and measured with an electronic area meter (Li-Cor, Lincoln, NE) so that certain parameters (e.g., EEFW adult feeding injury) could be compared on a per-area basis. Leaf pubescence was characterized by examining lower (abaxial) and upper (adaxial) leaf surfaces of leaves from each tree with a binocular microscope. Trichome density was subjectively rated as $0,1,2,3$, or 4 corresponding to glabrous (few or none), light, moderate, dense, or very dense, respectively.

\section{Pest Resistance Evaluations}

Density of leaf galls and leaf mines was assessed by two individuals on all trees in May 2006, 2008, and 2009. Sampling in 2006 and 2008 was performed by blindly selecting 10 or more shoots from all sides of the lower two-thirds of each tree and inspecting $\leq 10$ leaves per shoot (100 total leaves per tree). Sampling was slightly modified in 2009 when all leaves and pests on the terminal 30 $\mathrm{cm}$ of the new growth of 10 blindly-selected shoots per tree were counted. Numbers of mines or galls per infested leaf also were recorded. Mines were characterized by their distinctive shapes (serpentine, linear blotch, or blotch), until rearing had confirmed identity of their causal species. Six consecutive days with subfreezing temperatures (April 5-10, 2007; lows of -1.1, -3.9, -5.6, -5.6, -3.9 , and $-1.7^{\circ} \mathrm{C}$, respectively), damaged young leaves of earlyflushing cultivars, preventing comparisons of leaf miner and gall densities in that year. The trees however, re-foliated within a few weeks allowing the study authors to evaluate JB damage in 2007.

Representative leaf galls were dissected and the aphids within them were sent to S. Halbert for identification (Florida State Collection of Arthropods, Gainesville, FL). Voucher specimens were deposited in the Florida State Collection of Arthropods (FSCA\# E2008-4088). Approximately 200 mined leaves with late-instar larvae or pupae were held in the lab in translucent plastic containers with moist florist's foam to rear adults for identification. One of the two predominant species, Agromyza aristata Malloch (=A. ulmi), was identified via keys and descriptions (Needham et al. 1928; Spencer 1973). Adults of other abundant species, a leaf-mining weevil, were sent to R. Anderson (Canadian Museum of Natural History) who identified them as EEFW, which had not previously been reported in Kentucky. Voucher specimens are deposited in the University of Kentucky Insect Collection. Wholetree leaf area loss from skeletonization by Japanese beetles was visually estimated (nearest $10 \%$ ) by two independent observers just after peak flight each summer in late July 2006-2008. The two ratings were averaged to provide a single estimate for each tree which was used in the statistical analyses. Area-wide Japanese beetle populations were unusually low in 2009, as such, whole-tree defoliation ratings were not done in that year.

Relative resistance to Japanese beetles was generally consistent for particular cultivars from year to year except for the U. americana cultivar 'Prairie Expedition' which sustained disproportionately high injury in 2007, the year it was planted. To determine if 
Table 1. Elm species, hybrids, and cultivars evaluated for insect resistance in Lexington, KY, 2006-2009, with geographical origins and selected leaf characteristics.

\begin{tabular}{|c|c|c|c|c|c|c|}
\hline $\begin{array}{l}\text { Species or } \\
\text { parentage }\end{array}$ & Cultivar name & Abbr. & $\begin{array}{l}\text { Native } \\
\text { range }\end{array}$ & $\begin{array}{l}\text { Leaf area } \\
\left(\mathrm{cm}^{2}\right)\end{array}$ & $\begin{array}{l}\text { Leaves per } \\
\text { shoot }\end{array}$ & $\begin{array}{l}\text { Pubesc. } \\
\text { rating }{ }^{2}\end{array}$ \\
\hline \multirow[t]{6}{*}{ U. americana } & Valley Forge & $\mathrm{VF}$ & $\begin{array}{l}\text { N. America } \\
\text { [NA] }\end{array}$ & $28 \pm 4$ & $20 \pm 8$ & $0 / 3$ \\
\hline & Princeton & $\mathrm{PN}$ & & $31 \pm 5$ & $16 \pm 6$ & $0 / 3$ \\
\hline & Jefferson & $\mathrm{J}$ & & $29 \pm 8$ & $13 \pm 4$ & $1 / 3$ \\
\hline & New Harmony & $\mathrm{NH}$ & & $28 \pm 5$ & $19 \pm 5$ & $0 / 3$ \\
\hline & Lewis \& Clark & $\mathrm{PE}$ & & $43 \pm 10$ & $11 \pm 1$ & $0 / 1$ \\
\hline & Prairie Expedition & & & & & \\
\hline \multirow[t]{3}{*}{ U. parvifolia } & Emer II Allee & EA & $\begin{array}{l}\text { Japan, China, } \\
\text { Korea }[\mathrm{A}]\end{array}$ & $2 \pm 0.2$ & $142 \pm 47$ & $0 / 0$ \\
\hline & Athena Classic & A & & $2 \pm 0.4$ & $177 \pm 25$ & $0 / 1$ \\
\hline & Everclear Lacebark & E & & $2 \pm 0.5$ & $179 \pm 72$ & $0 / 1$ \\
\hline $\begin{array}{l}\text { U. propinqua } \\
\text { (JFS Bierberich) }\end{array}$ & Emerald Sunshine & ES & Japan $[\mathrm{A}]$ & $20 \pm 2$ & $34 \pm 13$ & $3 / 4$ \\
\hline U. wilsoniana & Prospector & $\mathrm{PR}$ & China $[\mathrm{A}]$ & $20 \pm 2$ & $27 \pm 8$ & $0 / 2$ \\
\hline \multirow[t]{2}{*}{$\begin{array}{l}\text { U. pumila } \times \\
\text { japonica }\end{array}$} & $\begin{array}{l}\text { Morton Plainsman } \\
\text { Vanguard }\end{array}$ & MP & $\mathrm{A} \times \mathrm{A}$ & $11 \pm 2$ & $40 \pm 13$ & $0 / 0$ \\
\hline & New Horizon & $\mathrm{Nh}$ & & $16 \pm 3$ & $53 \pm 14$ & $0 / 2$ \\
\hline \multirow{2}{*}{$\begin{array}{l}\text { U. japonica } \times \\
\text { wilsoniana }\end{array}$} & Morton Red Tip & MR & $\mathrm{A} \times \mathrm{A}$ & $8 \pm 2$ & $143 \pm 63$ & $1 / 1$ \\
\hline & Morton Accolade & M & & $16 \pm 1$ & $20 \pm 8$ & $0 / 0$ \\
\hline $\begin{array}{l}\text { U. pumila } \times \\
\text { japonica } \times \\
\text { wilsoniana }\end{array}$ & $\begin{array}{l}\text { Morton Glossy } \\
\text { Triumph }\end{array}$ & MG & $\mathrm{A} \times \mathrm{A} \times \mathrm{A}$ & $10 \pm 3$ & $70 \pm 26$ & $1 / 2$ \\
\hline $\begin{array}{l}\text { U. carpinifolia } \times \\
\text { pumila } \times \\
\text { wilsoniana }\end{array}$ & $\begin{array}{l}\text { Morton Stalwart } \\
\text { Commendation }\end{array}$ & MS & $\mathrm{A} \times \mathrm{A} \times \mathrm{A}$ & $12 \pm 3$ & $45 \pm 24$ & $1 / 2$ \\
\hline $\begin{array}{l}\text { U. glabra } \times \\
\text { carp. } \times \\
\text { pumila } \times \\
\text { wilson. }\end{array}$ & Patriot & PT & $\mathrm{E} \times \mathrm{A}$ & $10 \pm 2$ & $75 \pm 37$ & $1 / 3$ \\
\hline $\begin{array}{l}\text { U. carp. } \times \\
\text { U. parvifolia }\end{array}$ & Frontier & $\mathrm{F}$ & $\mathrm{E} \times \mathrm{A}$ & $4 \pm 0.4$ & $101 \pm 43$ & $0 / 0$ \\
\hline $\begin{array}{l}\text { U. glabra } \times \\
\text { carp. } \times \\
\text { pumila }\end{array}$ & Homestead & $\mathrm{H}$ & $\mathrm{E} \times \mathrm{E} \times \mathrm{A}$ & $4 \pm 0.5$ & $113 \pm 25$ & $0 / 0$ \\
\hline $\begin{array}{l}\text { U. glabra } \times \\
\text { carpinifolia }\end{array}$ & Pioneer & PI & $\mathrm{E} \times \mathrm{E}$ & $11 \pm 1$ & $48 \pm 5$ & $0 / 1$ \\
\hline
\end{tabular}

the tree truly is susceptible, a brief feeding trial was performed using only the American elm cultivars. Four nondamaged leaves, one from each cardinal direction, were harvested from each tree on July 28,2009 , brought to the laboratory, and measured with an area meter as before. The leaves were placed individually in Petri dishes on moist filter paper; then one field-collected female beetle that had been starved overnight was added. The leaves were re-measured after 18 hours to calculate the area that had been consumed. Data from the four leaves were averaged to provide a single value per tree, followed by two-way ANOVA to test for cultivar differences as before.

\section{Life History of Orchestes alni and A. aristata in Kentucky}

Observations and samples were taken to clarify the seasonal biology of EEFW and A. aristata. All trees of 'New Horizon' and 'Homestead', the two cultivars having the highest densities of EEFW mines in 2008, were examined weekly from March 24, 2009, before bud break of any cultivar, until midJune, and twice thereafter in July. On each date, two independent observers slowly circled each tree for two minutes while counting weevils on new growth in the lower two-thirds of the 
canopy; their counts were then averaged. Once mines appeared, 20 mined leaves (two to three per tree) were collected weekly, stored in $80 \% \mathrm{EtOH}$, and dissected to track larval and pupal development. Those leaves were taken from higher up in the canopy than where the mine counts were taken for assessing cultivar resistance. Samples of mined leaves were examined to determine frequency distributions for mines per leaf, and larvae per mine.

The hypothesis that phenological asynchrony between bud break, leaf flush, and onset of adult activity might account for cultivar resistance to EEFW was evaluated by comparing timing of bud break of two highly susceptible cultivars, 'New Horizon' and 'Homestead' with two resistant ones, 'Morton Accolade' and 'Jefferson'. The same hypothesis was tested for $A$. aristata by comparing bud break timing of highly susceptible 'Princeton' and 'Jefferson' with more resistant 'Valley Forge' and 'Prairie Expedition'. To keep other factors as consistent as possible, three of the four cultivars selected for testing the phenological asynchrony hypothesis with EEFW are hybrids ('Jefferson' is an American), and all four cultivars tracked for A. aristata are $U$. americana. Two independent observers rated the overall bud development of all trees of those cultivars on April 9, 2009, the first week weevils were observed at the site-as 1 (dormant bud), 2 (swollen bud), 3 (green tip bud), 4 (one fully emerged leaf), or 5 (two or more leaves). Ratings were averaged within trees and cultivars.

The hypothesis that elm cultivars resistant to EEFW mining also resist adult feeding was evaluated in early July by which time the weevils had chewed numerous holes in leaves of susceptible cultivars. Twenty leaves were randomly sampled from each tree on July 1, and taken to the laboratory where the characteristic feeding holes were counted. Counts were standardized to holes per $10 \mathrm{~cm}^{2}$ of leaf area.

\section{Statistical Analyses}

Percentage defoliation by Japanese beetles, and numbers of European elm flea weevil mines and adult feeding holes were analyzed by two-way analysis of variance (ANOVA) and pre-planned single degree of freedom linear contrasts between groups of elm species or parentages within each year. Percentages were arcsine square root-transformed and mine and hole counts were log-transformed to meet assumptions of normality and homogeneity of variances. ANOVA assumptions could not be met for pouch galls and the other two leaf miner species because all zeroes were documented for some cultivars, so the nonparametric Kruskal-Wallis test was used. Relationship between counts of EEFW larval mines and adult feeding holes was tested by Spearman rank correlation. Statistix version 9.0 (Analytical Software 2008) was used for all analyses. All data are reported as original means $( \pm \mathrm{SE})$.

\section{RESULTS}

\section{Pest Resistance Evaluations}

The different elms varied in susceptibility to Japanese beetles (Figure 3). Straight species and cultivars having Japanese origin (U. parvifolia and U. propinqua) were less susceptible than $U$. americana or $U$. wilsoniana which are native to North America and central China, respectively. Hybrid elms, as a group, were more heavily defoliated than any of the straight species (ANOVA, linear contrasts, $P<0.01$ ) although 'New Horizon' and 'Frontier', two cultivars having Japanese parentage, were consistently less susceptible than the other hybrid elms (Figure 3). However, 'Morton Glossy Triumph', the other hybrid with some Japanese (U. japonica) parent- age, was among the most susceptible cultivars. There was no overall relationship between Japanese beetle injury (three-year average) and pubescence rating (Spearman rank correlation 0.30, $P=0.19$ ). Mean pubescence rating also did not differ between the six most and six least resistant cultivars (Wilcoxon signed rank test, $P=0.33$ ).

There was no difference in Japanese beetles' consumption of 'Prairie Expedition' compared to the mean for other American elm cultivars in the supplemental feeding trial (ANOVA, linear contrasts, $P=0.98)$. Mean $( \pm \mathrm{SE})$ leaf area eaten of 'Prairie Expedi-

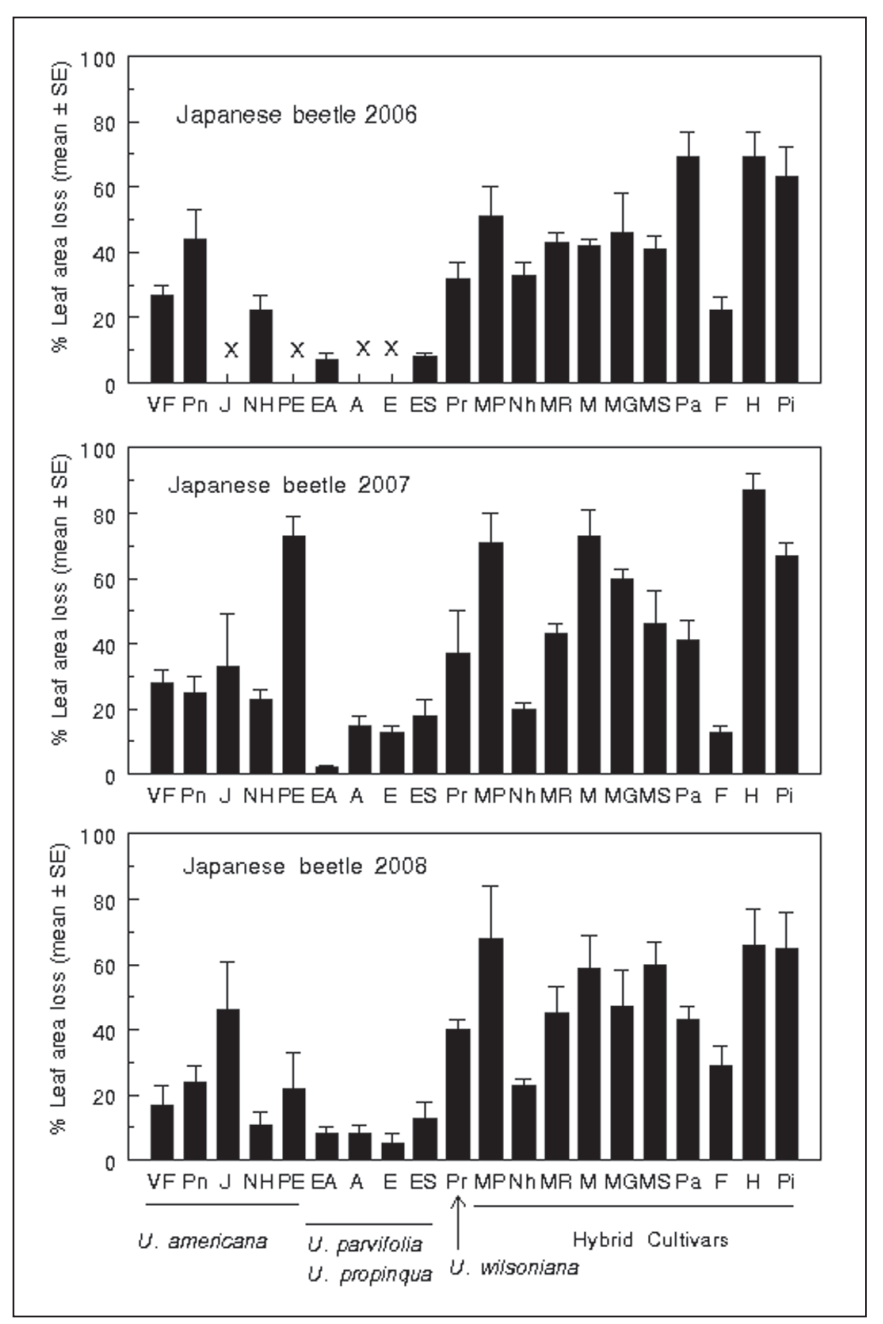

Figure 3. Cumulative leaf area loss by late July from Japanese beetle feeding on elms. Cultivar abbreviations are listed in Table 1. There were significant differences among cultivars (ANOVA, $P<0.001$ ) with the following significant differences (all $P<0.01$ ) indicated by linear contrasts in each year: 1) $U$. parvifolia + propiqua < americana; 2) U. parvifolia + propiqua < wilsoniana; 3) $U$. parvifolia + propiqua < all hybrids; 4) $U$. americana < all hybrids. For 2006, "X" denotes cultivars that had not yet been planted.

tion' compared to the other four cultivars was $1.80 \pm 0.43 \mathrm{~cm}^{2}$ versus $1.82 \pm 0.18 \mathrm{~cm}^{2}$, respectively, indicating that despite the heavy feeding that it incurred in the summer it was planted, 'Prairie Expedition' is not inordinately susceptible to Japanese beetles.

Club-like pouch galls (Figure 1) induced by the aphid Tetraneura nigriabdominalis were the only abundant insect-induced 
galls on the study trees. The galls, formed on the adaxial side of expanding leaves, were green at first, becoming bright red as the aphids developed, and later withering to brown after the aphids have matured. Individual pouch galls $(\mathrm{n}=36)$ dissected on May 8,2009 , contained a mean of $4.7 \pm 0.6$ aphids (range: $1-12$ ). Out of 91 galled leaves, the numbers having $1,2,3,4$, or $>4$ galls, were $75,4,5,2$, and 5, respectively. Some Tetraneura pouch galls were found on all species but they were particularly abundant on the $U$. pumila $\times U$. japonica hybrids 'Morton Plainsman Vanguard' and 'New Horizon' (Figure 4). Overall densities of pouch galls were much higher in 2009 than in 2006-2008. Small numbers of comb galls induced by the aphid Colopha graminis also were present but their numbers were too low for analysis.

Three different elm-infesting leaf miner species were found on the study trees (Figure. 1; Figure 2). Agromyza aristata (formerly Agromyza ulmi), a leaf-mining fly, was most abundant on U. americana but also found on U. wilsoniana and several of the hybrid elms (Figure 5). In contrast, Kaliofenusa (= Fenusa) ulmi Sunde-

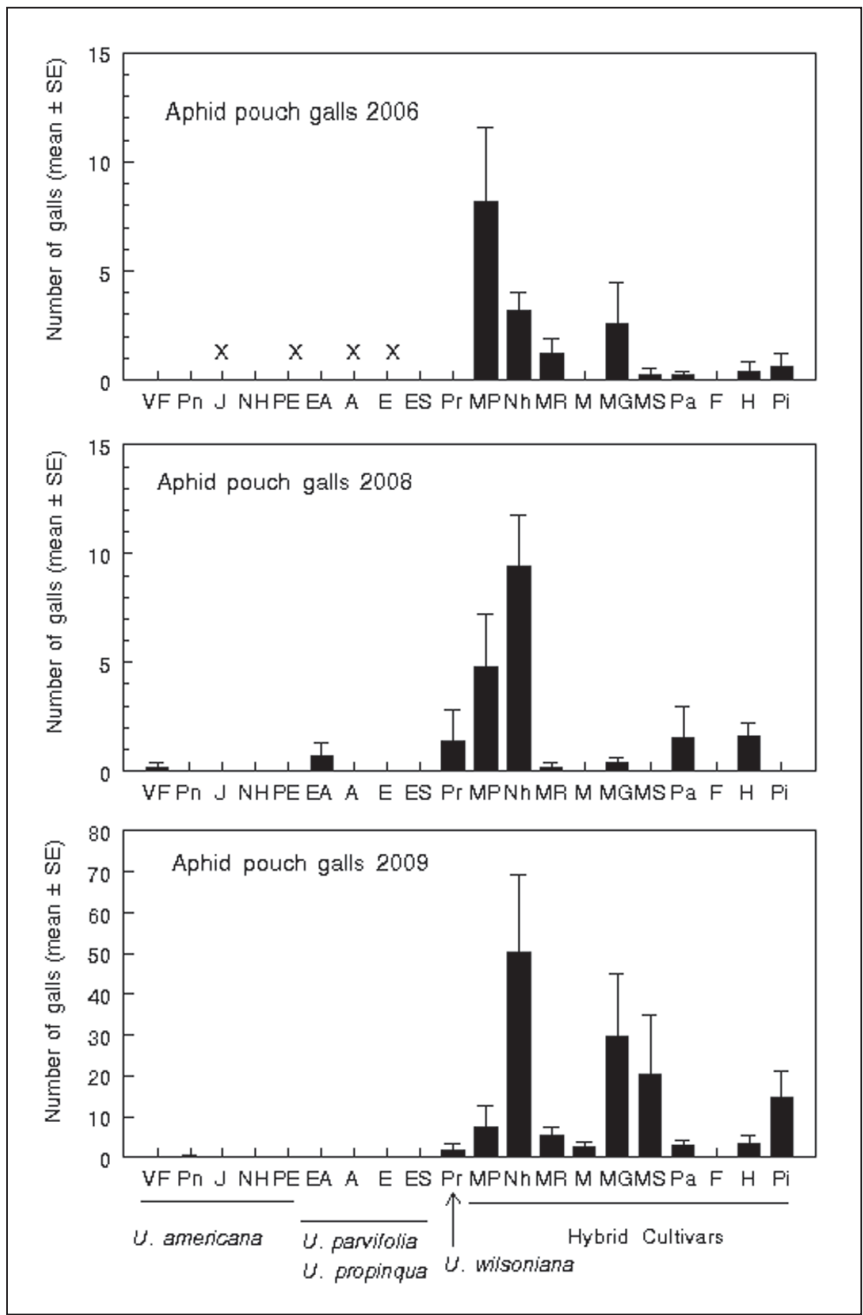

Figure 4. Abundance of aphid (T. nigriabdominalis) pouch galls on elm species and cultivars. There were significant differences among cultivars in each year (Kruskal- Wallis nonparametric ANOVA, $P<0.001$ ). For 2006, " $X$ " denotes cultivars that had not yet been planted. An April freeze killed the first flush of leaves of most cultivars in 2007. Data are number per 100 leaves (2006, 2008) or per ten $30 \mathrm{~cm}$ shoots (2009). vall (Hymenoptera: Tenthredinidae), a European sawfly that entered North America before 1898 (Smith et al. 1971), was relatively abundant on several of the hybrid cultivars, but either absent or uncommon on $U$. americana, and on the Asian species (Figure 6). Populations of A. aristata and F. ulmi were decimated by the April 2007 freeze that killed young leaves of most cultivars. By 2009, the latter species had rebounded but $A$. aristata densities remained much lower than in 2006 (Figure 5). EEFW, the invasive leafmining weevil first noticed on the elms in 2007 , had become the most abundant and destructive leaf miner at the study site by 2008 . Mines of these three species are readily distinguished: A. aristata forms a winding serpentine-blotch mine that typically begins at the leaf margin, K. ulmi causes large blotch or blisterlike mines, and EEFW forms a shorter linear-blotch mine that begins in the midvein and widens at the leaf margin, usually near the tip (Figure 1).

EEFW had the broadest host range among the three species of leaf miners at the study site. It was found on all species and hybrids, including 19 of the 20 cultivars evaluated. Abundance

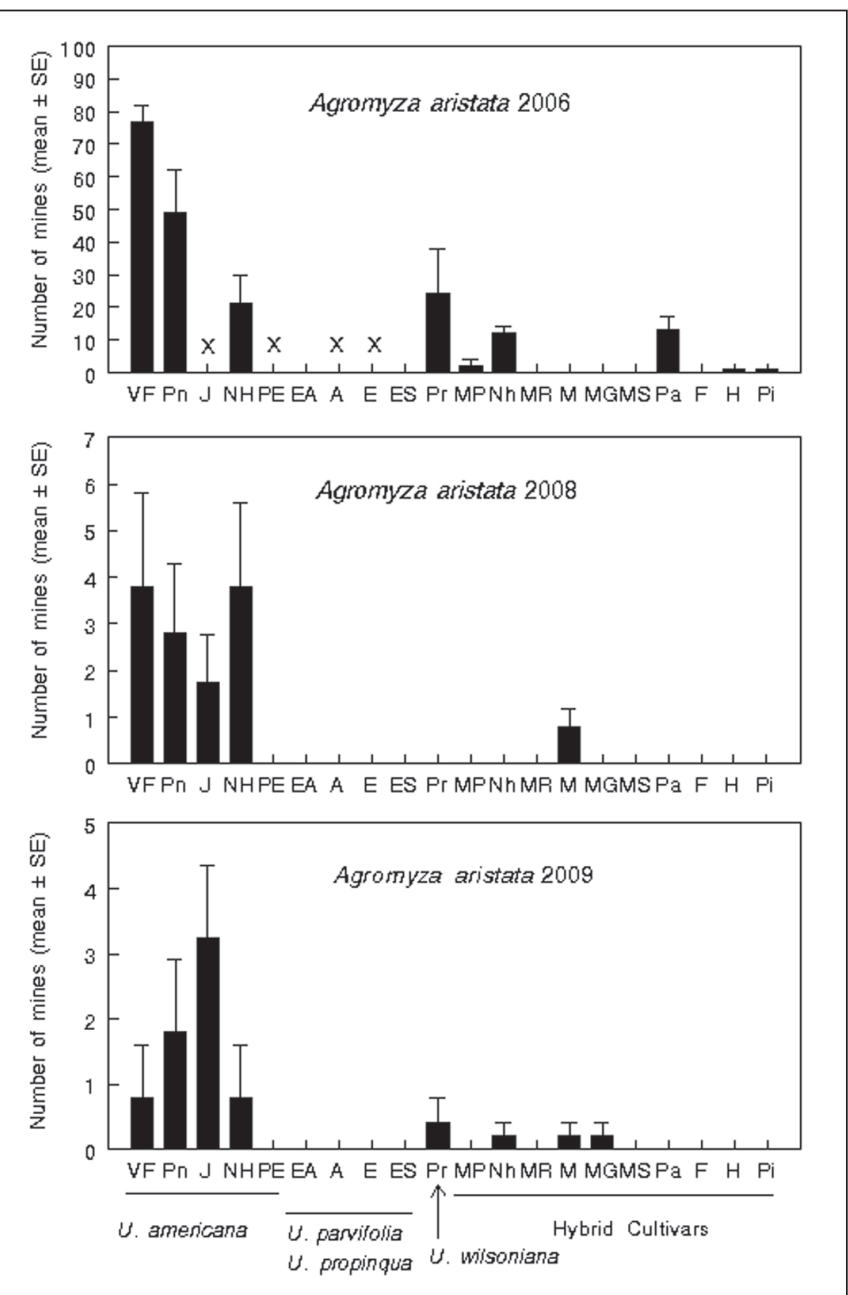

Figure 5. Abundance of $\boldsymbol{A}$. aristata leaf mines on elm species and cultivars. Cultivar abbreviations are listed in Table 1. See Figure 4 legend for sample sizes and statistical differences. 


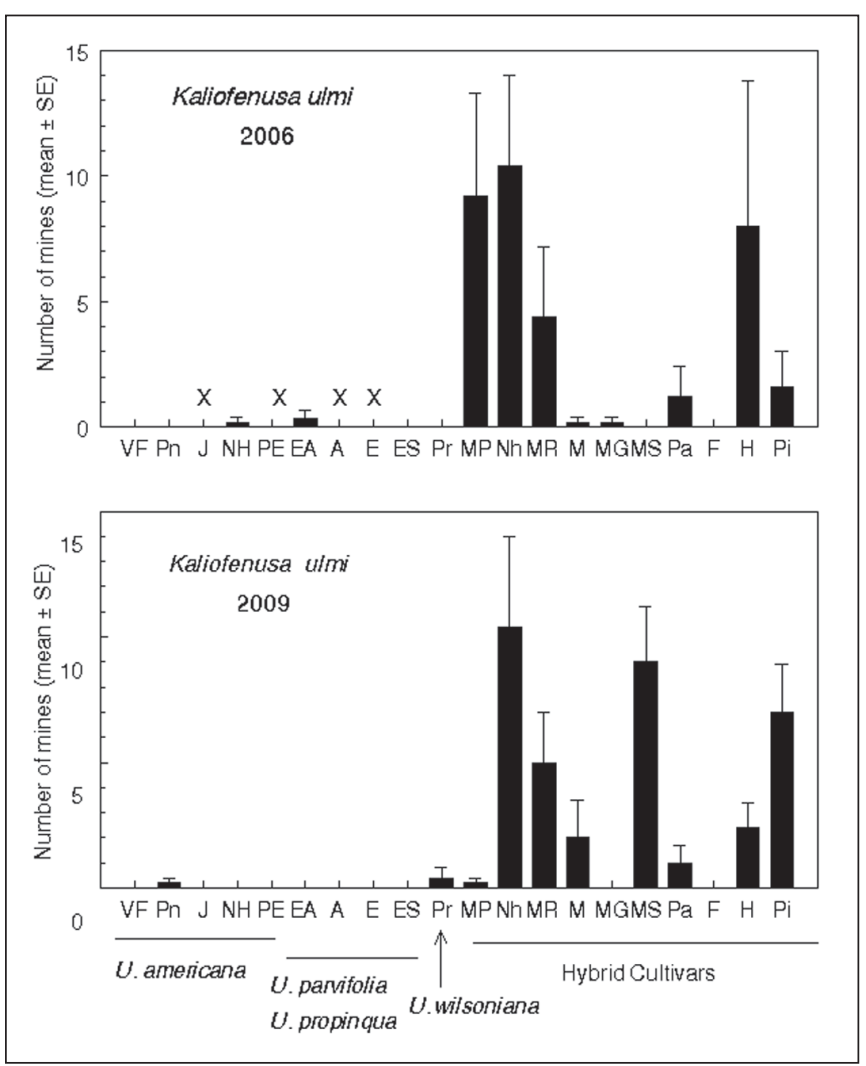

Figure 6. Abundance of $K$. alni leaf mines on elm species and cultivars. See Figure 4 legend for sample sizes and statistical differences.

of EEFW mines differed within and between elm species and parentages (Figure 7). American elm cultivars, as a group, were more resistant than Asian or hybrid cultivars (ANOVA, linear contrasts, $P<0.01$ ). There also was significant variation within elm species and parentages; e.g., U. americana 'Jefferson' and $U$. japonica $\times$ wilsoniana 'Morton Accolade' had particularly low numbers of EEFW mines in both 2008 and 2009 (Figure 7).

\section{Life History of Orchestes alni and A. aristata in Kentucky}

EEFW almost certainly overwinters as an adult. The weevils were first observed on susceptible cultivars on April 9, 2009, corresponding to accumulation of 88 Centigrade degree-days at base $10^{\circ} \mathrm{C}$ from January 1 (UK AG Weather Center 2009). Many mating pairs and the start of adult feeding damage were seen on young leaves of early-flushing cultivars at that time (Figure 8). There was no clear relationship, however, between timing of leaf flush and resistance to EEFW-the phenological ratings on April 9 had averaged 3 (dormant buds) and 1 (leaf tip emergence) for susceptible 'Homestead' and 'New Horizon', respectively, whereas resistant 'Jefferson' and 'Morton Accolade' were rated 2 (green tip buds) and 5 (>1 leaf fully expanded), respectively. Resistance to $A$. aristata also appeared not to be driven by bud break timing: susceptible 'Valley Forge' and 'Princeton' were both rated 2 (green tip buds) on April 9, whereas resistant 'Prairie Expedition' and 'Jefferson' were rated 2 and 4 (one expanded leaf), respectively.

European elm flea weevils oviposit in the underside of the mid-vein of young leaves leaving a visible scar. No EEFW mines

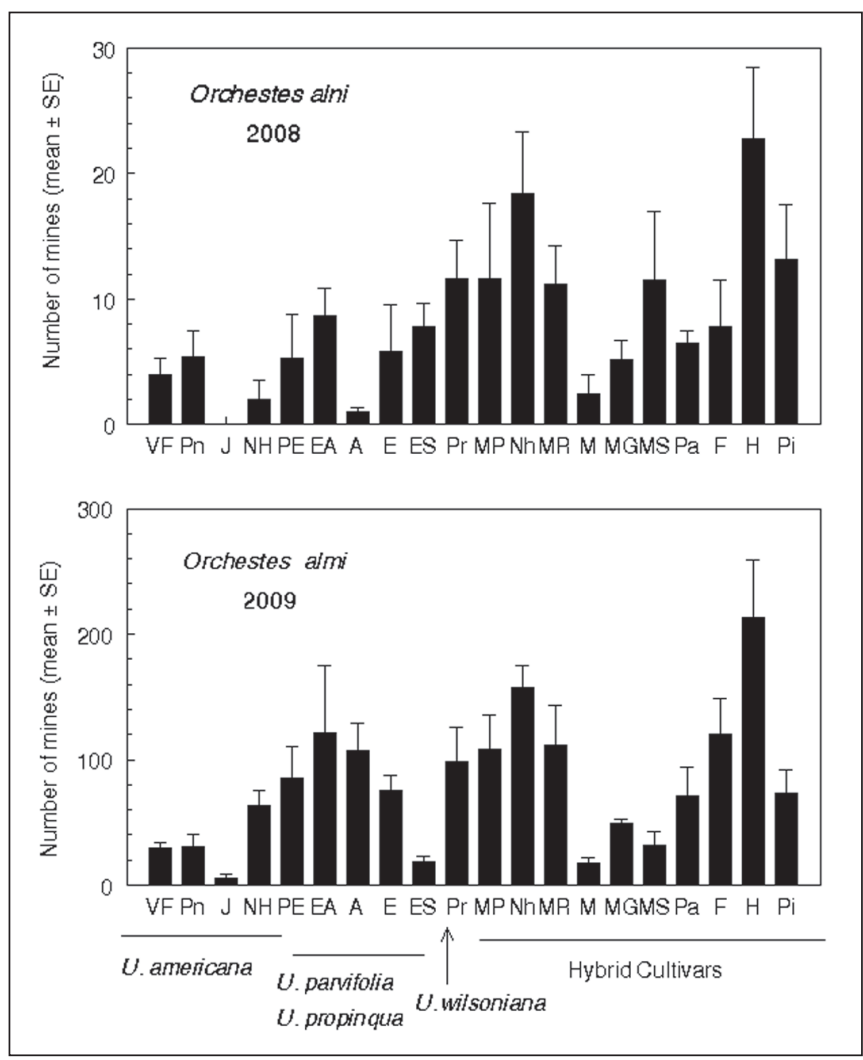

Figure 7. Abundance of European elm flea weevil, 0 . alni, leaf mines on elm species and cultivars. There were significant differences among cultivars (ANOVA, $P<0.001$ ) with the following significant differences (all $P<0.01$ ) indicated by linear contrasts in each year: 1) U. parvifolia + propiqua < americana; 2) $U$. parvifolia + propiqua < wilsoniana; 3 ) U. parvifolia + propiqua < all hybrids, 4) $U$. americana < all hybrids. Small numbers of weevils were first observed at the study site in 2007. Data here are number per 100 leaves (2008) or per ten $30 \mathrm{~cm}$ shoots (2009).

were apparent on April 23, but five days later (April 28) they were noticeable on many of the trees. The legless larvae are cream-colored with a dark brown head capsule, somewhat flattened, and deeply segmented (Figure 2). Larvae with three distinct sizes of head capsules were found in the weekly samples, suggesting three instars. Mines collected on April $28(n=20)$, contained first or second instars but a few third instars were present by early May. All dissected mines $(n=200)$ contained a single larva. In a sample of 180 mined leaves, 95\% (171) had a single mine and the numbers having 2,3 , or 4 mines were 6 , 2 , and 1 , respectively. All of the mines originated in the midrib except on the one leaf with four mines, on which one started in the midrib and the rest originated in lateral veins.

EEFW pupated in the mine. Pupae, which are yellowish with an obvious snout, were first observed on May 15. New adults began emerging May 23-29, and large numbers were feeding on the leaves by early June (Figure 8), but unlike in early spring, no mating pairs were observed at that time. By early July, they had riddled leaves of the more susceptible cultivars with dozens of feeding holes (Figure 2; Figure 8). Cultivars with relatively few mines had little adult feeding, and vice versa (Spearman rank correlation $0.89, P<$ 0.001 ; Figure $8 b$ ). Numbers of weevils on the elm foliage declined in mid-late June and by early July they had nearly disappeared from the 
tree canopies (Figure 8a). New leaves flushing in July had no adult feeding injury. There was only one leaf-mining generation per year.

The observations of the seasonal life history of A. aristata in Kentucky are consistent with an anecdotal account by Needham et al. (1928). The flies emerged in April and oviposited in newly expanding leaves. Eggs are usually inserted at or close to the leaf margin. The newly-hatched larva usually mines towards the leaf center, making a narrow linear pale-green track which often runs along a lateral vein and subsequently the mid-vein. The second instar widens the mine and creates lateral turns. After the second molt, the final (third) instar broadens the mine further to produce a brownish blotch mine (Figure 1). The mines are very noticeable by early May. In a sample of 36 mined leaves, most (89\%) had a single mine and the rest had two mines. All mines contain a single larva. In mid- to late-May the mature third instar cuts a semicircular slit, exits the mine, and falls to the ground where it pupates. There is one generation per year.

\section{DISCUSSION}

This study provides new information on relative resistance of commercially-available, Dutch elm disease-resistant elms to multiple insect pests. Variation in Japanese beetle feeding on Asian elm species

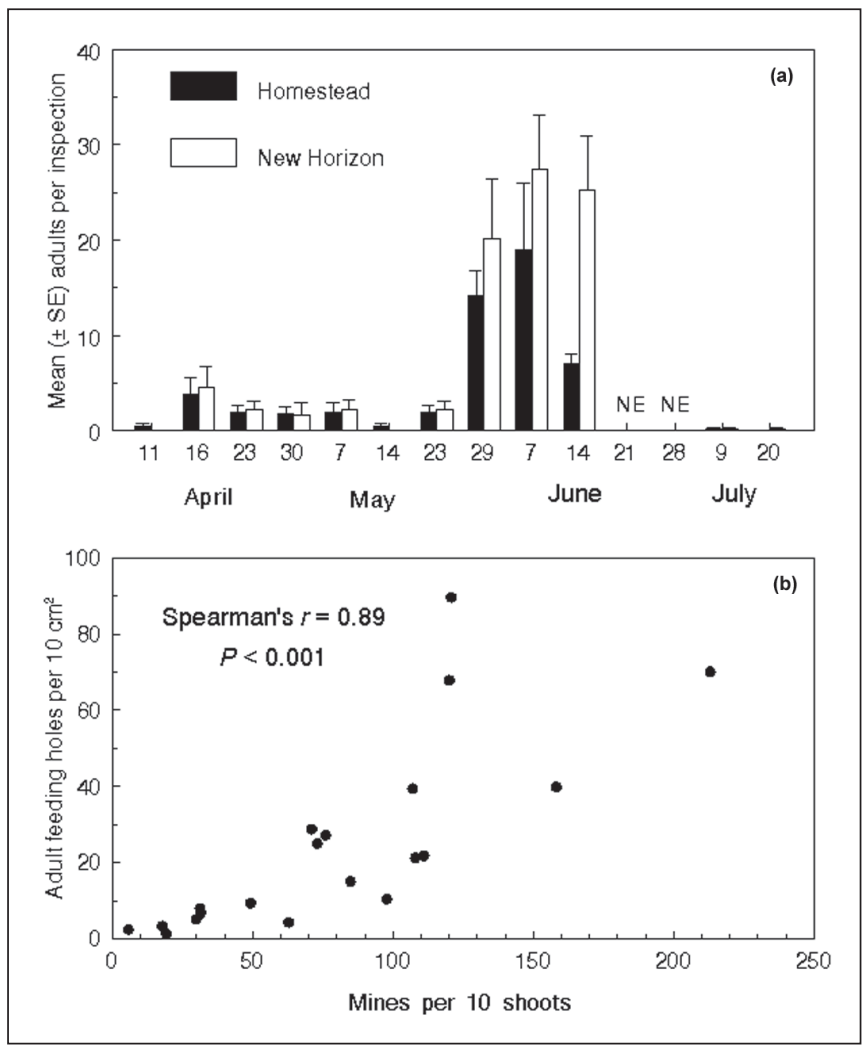

Figure 8. (a) Seasonal abundance of $\boldsymbol{O}$. alni adults on two susceptible elm cultivars in 2009 based on two-minute counts performed weekly from before bud break until mid-June, and on two dates in July. (b) Correlation between numbers of $O$. alni mines and weevil feeding scars showing that cultivars relatively resistant to mining also are less-damaged by the adults. Each point represents the mean for a different cultivar. The four most resistant cultivars were Jefferson (fewest mines/holes), Morton Accolade, Emerald Sunshine, and Morton Stalwart Commemoration. The four most susceptible were Homestead (most mines/holes), New Horizon, Emer II Allee, and Frontier. and hybrids, including a few common to this study, was previously documented in trials with detached leaves or leaf disks (Miller et al. 1999; Miller 2000; Miller et al. 2001). Laboratory assays may (e.g., Spicer et al. 1995) or may not (e.g., Ladd 1987) accurately predict differences in Japanese beetles' response in the field where olfactory and visual cues also mediate host selection (Loughrin et al. 1996; Rowe and Potter 1996; Rowe and Potter 2000). Although American elm is traditionally listed as a favored host for Japanese beetles (Fleming 1972), current data indicates cultivars of U. americana, as a group, are less susceptible than many of the hybrids of elm species originating from mainland Asia or Europe. U. parvifolia and U. propinqua, which originate from Japan, generally were less damaged than either American or hybrid elms, possibly reflecting their longer evolutionary interaction with $P$. japonica. In contrast, hybrids containing $U$. davidiana var. japonica (synonym of $U$. propinqua), $U$. pumila, or $U$. wilsoniana were heavily fed upon. Miller et al. (1999) also reported heavy feeding on complex hybrids of those species.

The basis for variation in elm resistance to Japanese beetles is presently unknown. Miller et al. (1999) suggested leaf pubescence on the Asian elms $U$. glaucescens, $U$. lamellose, and $U$. macrocarpa might account for low levels of feeding seen on them in their assays, but those species were not included in the National Elm Trial. Tilia tomentosa L., a resistant linden species, also has pubescent leaves (Potter et al. 1998). Among the more resistant elms in this study, some (e.g., 'Emerald Sunshine', 'New Harmony') have abundant straight or bent simple hairs (0.3-0.4 mm height) on the leaf underside, whereas others (e.g., 'Emer II Allee', 'Athena', 'Everclear') are glabrous or nearly so. Other factors such as secondary chemistry, leaf toughness, and leaf size (e.g., the three resistant $U$. parvifolia cultivars all have very small leaves) warrant investigation as possible resistance factors.

Bright red pouch galls induced by the aphid T. nigriabdominalis, although unlikely to impact tree vigor, were noticeable enough on some of hybrid cultivars (e.g., 'New Horizon') to possibly reduce the marketability of nursery trees. These aphids have a complex life history with a portion of the population alternating between galls on $\mathrm{Ul}$ mus spp., their winter and spring host, and roots of grasses, the summer host (Blackman and Eastop 1994; S. Halbert, pers. comm.). Flying females, called sexuparae, emerge from the grass roots in autumn, go to elms, and deposit tiny males and females (sexuales) on the bark. After mating, those females each lay one egg near a bud. In the spring, the eggs hatch and the nymph initiates a gall. Her all-female offspring are winged and after maturing fly out of the gall to colonize grass roots and start the cycle anew. Part of the population remains on grasses all the time (Blackman and Eastop 1994; S. Halbert, pers. comm.).

Kaliofenusa ulmi, introduced from Europe, is best-known of the three leaf miner species at the current study site. The adult sawflies emerge in spring and lay eggs in the upper leaf epidermis (Johnson and Lyon 1988). Eggs hatch in roughly one week and the legless, flattened larvae form blotch-like mines. After several weeks the mature larva drops from the leaf and burrows into the soil where it overwinters. There is one generation per year. A survey of $30 \mathrm{elm}$ accessions in Wisconsin (Guries and Smalley 1994) suggests Eurasian elms (including U. glabra) are highly susceptible, $U$. japonica and $U$. carpinifolia are less susceptible, and $U$. americana, $U$. parvifolia, and $U$. pumila are resistant to $K$. ulmi. Another survey at The Morton Arboretum in Illinois found far more $K$. ulmi mines on European elm species than on Asian or North American elms (Miller 2000). In the current study, $K$. ulmi was found almost exclusively on hybrid cultivars, some of which have European parentage (U. glabra, U. carpinifolia), but 
also others having only Asian parentage (e.g., 'New Horizon', 'Morton Glossy Triumph'). This data supports $U$. americana, $U$. parvifolia, and $U$. propinqua as relatively resistant to $K$. ulmi.

Agromyza aristata, the only North American dipteran leaf miner commonly associated with Ulmus spp. (Spencer 1973), was the most abundant leaf miner at the study site in 2006. It was found mainly on $U$. americana. It was decimated by extensive freeze damage to young leaves in April 2007 and its numbers remained relatively low through 2008 and 2009. Except for a brief biological synopsis (Needham et al. 1928), the authors' literature search found no previous published research on its life history.

EEFW is native to England and much of continental Europe (Pitkin et al. 2008). It was first reported in the Midwestern United States in 2003; by 2006, when this study was initiated, the European elm flea weevil had been documented only from Illinois and Wisconsin (Anderson et al. 2007). Findings from the present study are a new state record for Kentucky. Where and in what life stage EEFW overwinters was not confirmed. Anderson et al. (2007) speculated that adults overwinter on or near the host tree, noting their appearance on elm trees in the early spring, as the buds are beginning to expand. Those observations are consistent with current findings of numerous weevils mating and laying eggs in expanding leaves by early April. By 2009, EEFW had become so abundant on some elm cultivars that the brown, vacated mines and adult feeding holes compromised the aesthetic quality of the trees. Moreover, the European elm flea weevil damaged all species and cultivars of elms, albeit some more than others. An Internet search (August 11, 2009) yielded postings about EEFW outbreaks in Illinois, Wisconsin, Michigan, Ohio, Colorado, and other states, with particularly heavy damage on Siberian elm, U. pumila, and on the hybrid cultivar 'Homestead'. EEFW is destructive enough to be a pest of concern for production nurseries and could rival Japanese beetle in compromising the aesthetics of otherwise suitable elms in landscapes.

In summary, although none of the elms in the National Elm Trial is resistant to all insect pests, based on available data they do differ in susceptibility to particular pest species. U. parvifolia, U. propiqua, and most of the hybrid cultivars are resistant to A. aristata, whereas American elms as a group are susceptible to that leaf miner. In contrast, some hybrid cultivars (e.g., 'New Horizon') are highly susceptible to both $K$. ulmi and aphid pouch galls, which are absent or nearly absent on $U$. americana, parvifolia, and propinqua, whereas others (e.g., Frontier) are resistant to those pests. The two most destructive pests, Japanese beetle and EEFW, had the broadest host range. Most American elms showed some relative resistance to both, but 'Jefferson', which was highly resistant to EEFW, is susceptible to Japanese beetle damage. Notably, most of the hybrid cultivars, including the otherwise pest- and disease-resistant $U$. parvifolia cultivars, are susceptible to EEFW, an invasive pest that seems to be expanding its geographical range in the United States. Of the hybrids, 'Morton Accolade' was relatively resistant to EEFW whereas 'Homestead' was very heavily damaged by EEFW larvae and adults.

Awareness of such differences in resistance may help homeowners, landscapers, and urban foresters to select and plant elm trees that will simplify future pest management requirements. For example, U. parvifolia and U. propiqua would be good choices for areas where Japanese beetles are abundant, but might require periodic treatment for EEFW. Planting 'Jefferson' elms would likely limit the impact of EEFW, but managers would need to be prepared to implement Japanese beetle suppression. Development and release of Dutch elm disease-resistant Ulmus spp. has considerable promise for diversifying urban and suburban landscapes threatened by potentially lethal invasive insects and pathogens. Resistance to other native and exotic pests, such as the ones discussed herein, should also be a consideration for selecting the best-adapted and sustainable landscape trees for particular geographical regions.

Acknowledgments. We are grateful to J. Hartman and E. Dixon for planting and maintaining the University of Kentucky (UK) National Elm Trial plot and allowing us access to the trees. R.S. Anderson (Canadian Museum of Nature, Ottawa) and S.E. Halbert (Florida State Collection of Arthropods, Gainesville) kindly identified voucher specimens of European elm flea weevil and gall aphids, respectively. We thank C. Elder, J. George, V. Jacquier, B. Potter, and C. Redmond for help with data collection, R. Bessin who took some of the photos (Figures 1b, 1c; and Figures 2a, 2b), and J. Boggs (The Ohio State University) and J. Hartman (UK) for critically reading the manuscript. A grant from the UK Nursery Research Endowment partially supported this work. This is paper 0908-082 of the Kentucky Agricultural Experiment Station. The first and second authors contributed equally to this work.

\section{LITERATURE CITED}

Analytical Software. 2008. Statistix version 9.0; User's manual. Analytical Software, Tallahassee, FL.

Anderson, R.S., C.W. Obrien, G.A. Salsbury, and S.J. Krauth. 2007. Orchestes alni (L.) newly discovered in North America (Coleoptera: Curculionidae). Journal of Kansas Entomological Society 80:78-79.

Blackman R.L., and V.F. Eastop. 1994. Aphids on the world's trees. CAB International. Wallingford, UK.

Bosu, P.P., F. Miller, and M.R. Wagner. 2007. Susceptibility of $32 \mathrm{elm}$ species and hybrids (Ulmus spp.) to the elm leaf beetle (Coleoptera: Chrysomelidae) under field conditions in Arizona. Journal of Economic Entomology 100:1808-1814.

Brasier, C.M., and M.D. Mehrotra. 1995. Ophiostoma himal-ulmi sp. Nov., a new species of Dutch elm disease fungus endemic to the Himalayas. Mycological Research 99:205-215.

Guries, R.P., and E.B. Smalley. 1994. Variation in elm leafminer injury on elms in Wisconsin, pp. 62-78. In: Proc. 8th METRIA Conf., Metropolitan Tree Improvement Alliance, U.S. National Arboretum, Washington, D.C.

Hubbes, M. 1999. The American elm and Dutch elm disease. Forestry Chronicle 75:265-273.

Jacobi, W., J. Klett, and J. Walla. 2009. National Elm Trial overview. $<$ http://treehealth.agsci.colostate.edu/research/nationalelmtrial/NationalElmTrial.htm>.

Johnson, W.T., and H.H. Lyon. 1988. Insects that feed on trees and shrubs, 2nd Edition. Cornell Univ. Press, Ithaca, NY.

Ladd, T.L., Jr. 1987. Japanese beetle (Coleoptera: Scarabaeidae): Influence of favored food plants on feeding response. Journal of Economic Entomology 80:1014-1017.

Loughrin, J.H., D.A. Potter, T.R. Hamilton Kemp, and M.E. Byers. 1996. Role of feeding-induced plant volatiles in aggregative behavior of the Japanese beetle (Coleoptera: Scarabaeidae). Environmental Entomology 25:1188-1191.

Merkle, S.A., G.M. Andrade, C.J. Nairn, W.A. Powell, and C.A. Maynard. 2007. Restoration of threatened species: a noble cause for transgenic trees. Tree Genetics \& Genomes 3:111-118.

Miller, F. 2000. Insect resistance of elm genotypes, pp. 137-154. In: C.P. Dunn (Ed.). The elms: Breeding, conservation, and disease management. Kluwer, Boston. 
Miller, F., S. Jerdan, and G. Ware. 1999. Adult Japanese beetle (Coleoptera: Scarabaeidae) feeding preference for Asian elm species and hybrids. Journal of Economic Entomology 92:421-426.

Miller, F., G. Ware, and J. Jackson. 2001. Preference of temperate Chinese elms (Ulmus spp.) for the adult Japanese beetle (Coleoptera: Scarabaeidae). Journal of Economic Entomology 94:445-448.

Needham, J.G., S.W. Frost, and B.H. Tothill. 1928. Leaf-mining insects. Williams and Wilkins, Baltimore, MD.

Pitkin, B., W. Ellis, C. Plant, and R. Edmunds. 2008. The leaf and stem mines of British flies and other insects. <http://www.ukflymines. co.uk/Beetles/Orchestes_alni.html>.

Potter, D.A., P.G. Spicer, D. Held, and R.E. McNiel. 1998. Relative susceptibility of cultivars of flowering crabapples, lindens, and roses to defoliation by Japanese beetles. Journal of Environmental Horticulture 16:105-110.

Raupp, M.J., A.B. Cumming, and E.C. Raupp. 2006. Street tree diversity in eastern North America and its potential for tree loss to exotic borers. Arboriculture \& Urban Forestry 32:297-304.

Rowe, W.J., and D.A. Potter. 1996. Vertical stratification of feeding by Japanese beetles within linden tree canopies: selective foraging or height per se? Oecologia 108:459-466.

Rowe, W.J., and D.A. Potter. 2000. Shading effects on susceptibility of roses, Rosa sp. to defoliation by Japanese beetles, Popillia japonica Newman. Environmental Entomology 29:503-508.

Smalley, E.B., and R.P. Guries. 1993. Breeding elms for resistance to Dutch elm disease. Annual Review of Phytopathology 31:325-352.

Smith, D.R. 1971. Nearctic sawflies. III. Heterarthrinae: adults and larvae. U.S. Dept. Agric. Tech. Bull. 1420.

Spencer, K.A. 1973. Agromyzidae (Diptera) of economic importance. Dr. W. Junk B.V., The Hague. 418 pp.

Spicer, P.G., D.A. Potter, and R.E. McNiel. 1995. Resistance of flowering crabapple cultivars to defoliation by the Japanese beetle (Coleoptera: Scarabaeidae). Journal of Economic Entomology 88:979-985.

Stipes, R.J., and R.J. Campana. 1981. Compendium of elm disease. Amer. Phytopathological Society, St. Paul, MN.

UK AG Weather Center. 2009. Ag Weather Center, Department of Biosystems \& Agricultural Engineering, University of Kentucky. <http:// wwwagwx.ca.uky.edu>.

\section{Jennie M. Condra \\ Department of Entomology \\ S-225 Agricultural Science Cntr. N \\ University of Kentucky \\ Lexington, KY 40546-0091,U.S.}

\author{
Cristina M. Brady \\ Department of Entomology \\ S-225 Agricultural Science Cntr. N \\ University of Kentucky \\ Lexington, KY 40546-0091,U.S.
}

\section{Daniel A. Potter (corresponding author) \\ Department of Entomology \\ S-225 Agricultural Science Cntr. N \\ University of Kentucky \\ Lexington, KY 40546-0091,U.S. \\ dapotter@uky.edu}

Résumé. Vingt génotypes d'ormes (Ulmus spp.) ornementaux résistants à la maladie hollandaise de l'orme ont été évalués lors de la reproduction d'une étude sur le terrain en regard de la résistance face à de multiples insectes parasites à Lexington dans le Kentucky (États-Unis). L'orcheste européen de l'aulne, Orchestes alni, un parasite récemment introduit qui défigure les ormes en minant et en mangeant les feuilles, a été listé dans le bilan le plus récent; aussi ses préférences en terme d'alimentation et de cycle de vie ont donc fait l'objet d'un suivi. $U$. parvifolia et $U$. propinqua, originaires du Japon, étaient relativement résistant aux scolytes japonais et $U$. americana était généralement moins susceptible que les autres hybrides. Agromyza aristata, un mineuse serpentine des feuilles, préférait les ormes d'Amérique, tandis que Kaliofenusa ulmi-une mineuse en taches-et Tetraneura nigriabdomidalis - un insecte suceur à galles-étaient peu présents chez les ormes américains et asiatiques mais abondants chez certains hybrides. L'orcheste européen de l'aulne infestait tous les ormes , et avec les densités les plus élevées-soit plus de 20 galeries par $30 \mathrm{~cm}$ de longueur de pousse et plus de 85 trous d'alimentation au stade adultechez certains hybrides. Les ormes américains, spécifiquement 'Jefferson', étaient en quelque sorte moins susceptibles. L'orcheste européen de l'aulne pondait ses œufs lors de l'expansion des feuilles; les galeries de minage étaient initiées à la fin avril et complétées vers la mi ou la fin mai. Les adultes nouvellement émergés causaient des dommages importants aux feuilles à la fin mai et en juin, mais disparaissaient par la suite de la cime des arbres vers la mi-juillet. Les implications de la réintroduction des ormes en milieu urbain sont discutées.

Zusammenfassung. Es wurden in Lexington, Kentucky, zwanzig Genotypen von Landschafts-geeigneten, gegen Ulmenkrankheit resistente Ulmenarten in einer Feldstudie auf Ihre Resistenz gegenüber verschiedenen Schadinsekten bewertet. Der europäische Ulmenflohkäfer (EEFW), ein kürzlich eingeführtes Schadinsekt, welches Ulmen durch Minieren der Blätter und Fraßschäden schädigt, hatte einen auffällig großen Schaden angerichtet, so daß nun der Lebenszyklus und Fressgewohnheiten überwacht werden. $U$. parvifolia und $U$. propinqua, ursprünglich aus Japan, waren relative resistant gegenüber Japankäfern und $U$. americana war weniger anfällig als die meisten Hybriden. Agromyza aristata, eine gewundene Blattminierfliege, favoritisierte Amerikanische Ulmen, während Kaliofenusa ulmi, eine Blattfleckenminierfliege und eine Laus (Tetraneura nigriabdominalis) eher ungewöhnlich auf Amerikanischen und Asiatischen Ulmen waren, aber in großer Zahl auf verschiedenen, bestimmten Hybriden. Der EEFW befällt alle Ulmen, aber mit höchster Dichte (>20 Gänge pro 30 $\mathrm{cm}$ Trieb und $>85$ Fraßlöcher von erwachsenen Käfern) auf bestimmten Hybriden, Amerikanische Ulme, besonders 'Jefferson', waren etwas weniger anfällig. Der EEFW legt seine Eier in wachsende Blätter, die Minen werden Ende April angelegt und Mitte bis Ende Mai beendet. Die neu geschlüften Käfer schädigen die Blätter von Mai bis Juni und verschwinden dann aus der Krone gegen Mitte Juli. Es wird über die Auswirkungen der erneuten Einführung von Ulmen in die urbanen Landschaften diskutiert.

Resumen. Se evaluaron veinte genotipos de olmos (Ulmus spp) resistentes a la enfermedad holandesa del olmo en un estudio de campo replicado para conocer la resistencia a múltiples plagas de insectos en Lexington, Kentucky, U.S. Se encontró el insecto europeo del olmo (EEFW), Orchestes alni, y fue monitoreada una plaga recientemente introducida que desfigura a los olmos por el minado de la hoja y alimentación de los adultos. $U$. parvifolia y U. propinqua, originalmente del Japón, fueron relativamente resistentes a los escarabajos japoneses, y $U$. americana fue generalmente menos susceptible que la mayoría de los híbridos. Agromyza aristata, una mosca serpentina minadora, prefirió los olmos americanos, mientras que Kaliofenusa ulmi, una mosca sierra minadora y las agallas de un áfido (Tetraneura nigriabdominalis) raras veces estuvieron en olmos americanos y asiáticos pero sí fueron abundantes en ciertos híbridos. EEFW infestaron todos los olmos en altas densidades, $>20$ minas por $30 \mathrm{~cm}$ de extensión y $>85$ agujeros de alimentación de adultos por hoja, en ciertos híbridos. Los olmos americanos, especialmente 'Jefferson', fueron menos susceptibles. EEFW depositó huevos en las hojas; las minas se iniciaron a fines de Abril y estuvieron completas para mediados a fines de Mayo. Los adultos recién emergidos dañaron extensivamente las hojas a fines de Mayo y Junio pero casi desaparecieron de las copas para mediados de Julio. Se discuten las implicaciones de la introducción de olmos en ambientes urbanos. 